\title{
Doroczne spotkanie Rady Naukowej i Recenzentów „Kardiologii Polskiej” \\ Katowice, 22.09.2017 r.
}

W trakcie tegorocznego Międzynarodowego Kongresu Polskiego Towarzystwa Kardiologicznego w Katowicach po raz szósty w historii naszego periodyku przyznano nagrody tym wszystkim, którzy najbardziej zapracowali na Impact Factor (IF) przyznany za 2016 rok. Jedną z nagród — statuetek (niezależnie od tego, w której z dwóch kategorii) można otrzymać tylko dwa razy. Gdyby nagroda miała trafić po raz trzeci do tej samej osoby, osoba ta otrzyma zamiast niej honorowy dyplom, a jej nagrodę przejmie kolejna osoba/praca z listy rankingowej. Kierując się tą regułą, Nagrody dla Najczęściej Cytujących „Kardiologię Polską" z lat 2014-2015 w 2016 roku otrzymali: dr hab. n. med. Artur Dziewierz (I Nagroda), dr hab. n. med. Zbigniew Siudak (II Nagroda) oraz dr n. med. Łukasz Rzeszutko (III Nagroda) — wszyscy pochodzący z ośrodka kierowanego przez prof. Dariusza Dudka z Krakowa, a dyplomy honorowe - prof. Grzegorz Opolski, prof. Dariusz Dudek, prof. Krzysztof J. Filipiak. Najczęściej cytowaną pracą (I Nagroda) z lat 2014-2015 w pismach filadelfijskich na świecie w 2016 roku okazała się publikacja dr. n. med. Łukasza Rzeszutko i wsp. z numeru 12/2014 "Kardiologii Polskiej” (polski rejestr zabiegów ze stentami bioresorbowalnymi), a tuż za nią uplasowały się artykuły: dr. hab. n. med. Filipa M. Szymańskiego i wsp. (współwystępowanie bezdechu sennego u pacjentów z migotaniem przedsionków, artykuł opublikowany w numerze 8/2014) oraz dr. hab. n. med. Marka Gierlotki i wsp. (polski rejestr ostrych zespołów wieńcowych z lat 2009-2012, artykuł opublikowany w numerze 3/2015). Specjalną okolicznościową statuetkę wręczono wydawcy pisma - firmie VIA MEDICA z Gdańska, w związku z historycznym przekroczeniem granicy wartości IF 1,00 w tym roku przez „Kardiologię Polską". Nagrodę w imieniu Prezesa Wydawnictwa — dr. n. med. Janusza Popaszkiewicza — odebrał dyr. Łukasz Kuban. Wśród laureatów, już od 6 lat, zabrakło kilku znanych i ważnych polskich kardiologów, często publikujących na świecie, ale liczymy, że także i oni włączą się w końcu w cytowanie narodowego pisma polskich kardiologów. Poniżej nasz fotoreportaż:
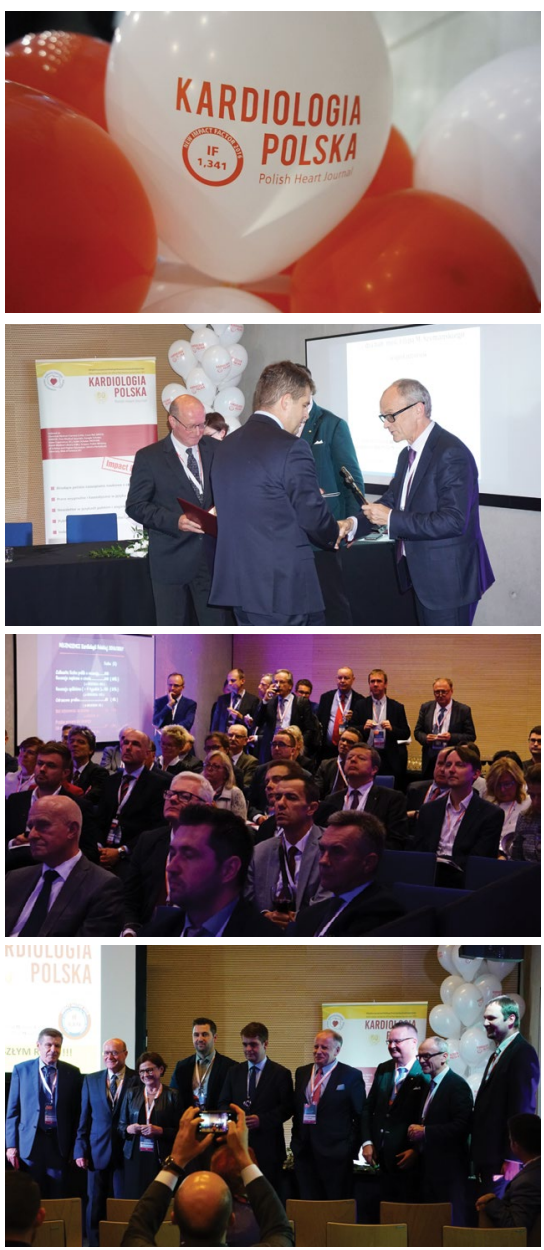
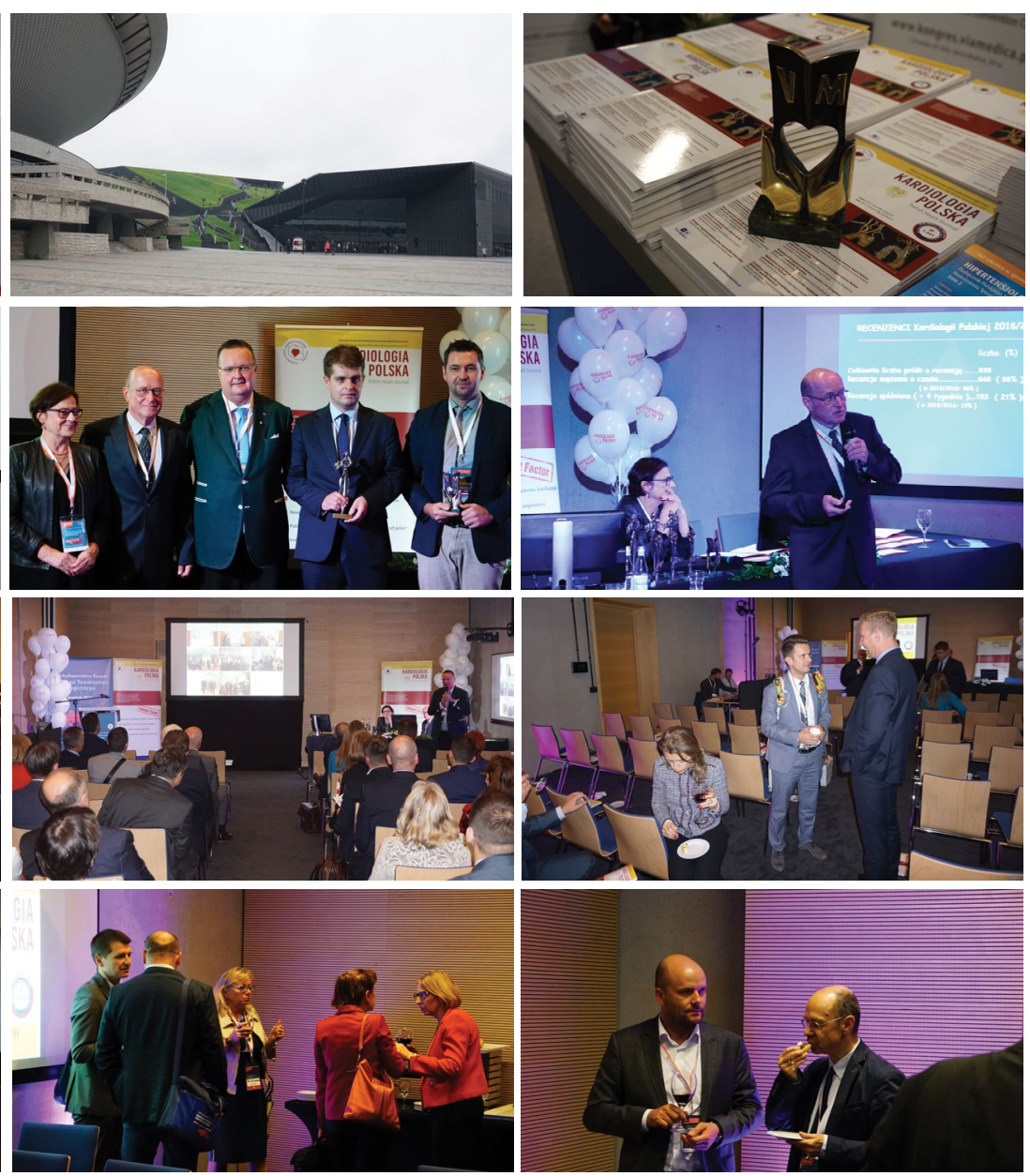
